\title{
Editorial
}

\section{Whither brand management?}

This issue of The Journal of Brand Management is full of good things, with all the papers shedding some light on contemporary brand management problems. I do not want the readers to delay too long before they get into the substance of these papers. However, in this autumn of our discontent, I would like to pose a few questions about the future marketing environment. (I am paid to think about post-millennial times!)

The first set of questions relate directly to customers, and are of obvious importance to the custodians of brands. The remaining sets are more broadly focused, but it does not take a great leap of the imagination to connect them all to brand management. The last group of questions relates to the current wave of questions about marketing itself. As $\mathrm{Na}$ tional Chairman elect of the Chartered Institute of Marketing, you will understand why I am concerned with these types of questions.

\section{CUSTOMERS}

This refers to both consumers, business end users, and distributors.

(1) How do customers define value and satisfaction? Does one have access to any methodology that really explores these issues?

(2) From what base does one build customer loyalty?

(3) How do customers trade off quality and price?

(4) Can one any longer reach customers by mass advertising?

(5) What implications does globalisation have for local identity - does local identity have any meaning in a world of global brands?

\section{MARKETS}

(1) Have we begun to understand the implications for markets of the informationbased, post-industrial society?

(2) Market saturation is a common characteristic of Western developed economies with too many goods and services chasing too few discretionary spending customers - can marketers find solutions to this problem?

(3) Too few discretionary spending customers - is this the beginnings of bipolar society, with high-income knowledge workers as a small minority, surrounded by a low-income proletariat?

(4) If markets are dominated by global producers and/or distributors, will there be any space for small and medium-sized enterprises?

\section{TECHNOLOGY}

Will the convergence of computing and telecommunications lead to:

(1) The dominance of direct marketing at the expense of national advertising?

(2) Efficiency drives in producing companies so that real time productivity analysis will expose unprofitable products, customers and outlets? Will outlets quickly delist unprofitable brands?

(3) Customer-based market analysis with redundancy risk for data-based analysis (based on aggregate Census data)? Will life style analysis come to dominate consumer market analysis?

(4) Reduction of the distance between suppliers and their customers by way of electronic data interchanges, electronic mail, voice mail, video conferencing and 
videophone? Who will become the communicators?

(5) Interactive marketing? If cable reaches 25 per cent of the estimated 50 per cent of all United Kingdom households with satellite/cable (expected by the year year 2000), then interactive marketing, voting, home shopping and game playing will touch a significant proportion of all householders. Who will be the interaction managers?

(6) New product development and testing based on new interactive/response mechanisms? What are the implications for co-designing and co-makership and where does marketing fit in?

\section{COMMUNICATIONS}

Technology is already revolutionising both information access and communications. What are the marketing implications of the following factors?

(1) Interactive marketing - dealing directly with the human face of the customer? Multimedia is the human face of electronic information!

(2) An advertising industry showing the same globalising tendencies as is manufacturing. What are the implications for marketing of a global oligopoly in advertising - eight or ten world conglomerate communications companies?

\section{DISTRIBUTION}

The concentration of ownership in UK distribution raises a number of questions:

(1) Has the rise of retailer power begun the process of destroying national brands? Is brand management, which in the past has been the apprenticeship route of many marketing directors, coming to the end of its life?
(2) Will competitive advantage lie with those marketing organisations that are really close to the customer, ie retailers?

(3) Will retailer brands and corporate brands dominate markets?

\section{MARKETING ORGANISATION}

Is the current criticism of marketing due to all (or some) of the following factors?

(1) A failure to distinguish between the marketing concept and marketing function.

(2) A failure to decide whether marketing is a holistic concept or a specialist subject.

(3) A failure to see that the only thing that really matters is that strategic thinking is dominated by marketing imperatives.

(4) A failure to match the claims of finance and manufacturing/engineering/research and development in respect of sovereignty over boardroom decision making.

(5) A failure to discern that marketing and sales are inseparable.

(6) A failure to understand that internal marketing must precede external marketing.

(7) A failure to realise/understand that the marketing concept is the only strategic vision that can forge value-added relationships with customers, employees and suppliers.

But what about the answers? I have views about most of them, but given the high intelligence of the readership of this Journal, I am asking for your responses to any or all of the questions. Given a reasonable response, I will return to print within twelve months with some of my own and your answers.

\section{Michael J. Thomas Editorial Board}

Professor Thomas can be reached by fax on 041-5522802 